\title{
Analysis on the Connotation of Rural Financial Products and Services Innovation
}

\author{
Ming-Gui CAO ${ }^{1, a,{ }^{*}}$, Ling $\mathrm{LI}^{2, \mathrm{~b}}$ \\ ${ }^{1}$ Department of Tourism, Xinyang Normal University, Xinyang 464000, China \\ ${ }^{2}$ Department of Economy, Xinyang Normal University, Xinyang 464000, China \\ acmg68@163.com, ${ }^{\mathrm{b}}$ 1055824378@qq.com \\ Corresponding author: Ming-Gui CAO
}

Keywords: Rural finance, Financial products and services, The issues of "agriculture, Rural areas and farmer", The connotation of rural financial products and services Innovation.

\begin{abstract}
The construction of a well-off society in all-round way need to solve the issues of "agriculture, rural areas and farmer", which requires rural financial support. The key to support rural financial is the innovation of rural financial products and services. Understanding the connotation of rural financial products and services innovation scientifically in favor of promoting the innovation of rural financial products and services. This paper will analyze the background of rural financial products and service innovation. Through the interpretation of the relevant national support policies and summarize the understanding of its connotations from domestic and foreign academia, so as to analyze the connotation of rural financial products and service innovation. Summarize its features: creativity, marketability, high Investment, high risks, reference, relatively conservative and rural. In the end, this paper presents the content of rural financial products and services innovation. It main includes enriching the content of rural financial products, stabilizing rural financial product pricing mechanism, developing intermediary service, innovating the collaboration pattern between insurance products and financial institutions, the concept of financial service, financial service process, the way of financial services, the management of financial services.
\end{abstract}

\section{The Background of Proposing Rural Financial Products and Services Innovation}

In recent years, China gradually increase the input of the "agriculture, rural areas and farmer" through the implementation of various comprehensive or direct subsidies fiscal policies, such as the reduction of agricultural tax, direct subsidies for grain-growing farmers. Thanks to these polices, the farmers' income has been greatly improved. Agricultural production has made great progress. China has gradually developed into a modern country. The rural overall landscape is changing with each passing day. However, the rural areas have not changed their backwardness fundamentally in the face of the fact that the gap between urban and rural areas is still huge.

The issues of "agriculture, rural areas and farmer" need to be resolved urgently, as it not only relates to the vital interests of the vast majority of people, especially for such a large agricultural country with $70 \%$ farmers, but also relates to social and economic development. All in all , to solve the problem about "agriculture, rural areas and farmer "is playing an vital role in promoting social and economic development, improving people's livelihood and building a harmonious society .[1].However, in order to achieve the target, rural finance is a strong pillar. The 18th CPC National Congress reports made clear that promoting financial innovation and developing financial services real economy. is extremely urgent. China's economic and social development, resulting in a number of emerging industries, and these emerging industries will naturally put forward new demand for financial services. Coupled with the original financing problem, encouraging financial innovation to meet the ever-changing society, to meet the diverse needs of financial services in various fields is the fundamental way.

For years, although the central government and the financial sector has carried on the various efforts and china's rural financial reform has been carried out, the results are not ideal. For of not to consider the "agriculture, rural areas and farmer" characteristics for the agriculture, rural areas and 
farmer" as a breakthrough, grasp the actual situation of rural financial institutions, Also it will naturally present the rural financial institutions and rural economic development is not ideal. Rural capital flow more and more serious, the rural economy main body increasingly lack in terms of money. According to the analysis of relevant data, by the end of 2015, China's total number of bank branches in rural areas reached 121,700, the number of bank outlets per million people have only 1.31, a serious financial problem of insufficient supply of subject [2] .To crack the problem about "agriculture, rural areas and farmer", we must break the rural financial problems. In order to change this situation, the innovation of rural financial products and services is very essential. Rural financial institutions to explore the characteristics and needs of the "agriculture, rural areas and farmer", and actively explore the effective way of financial products and services. Through the financial products and services to meet the needs of various subjects in rural areas, It is committed to improve the financial market system and promote rural economic growth greatly.

\section{The Importance of Developing Rural Financial Products and Service Innovation}

It is the key factor to promote rural financial innovation for the development of financial industry. In order to realize the rural financial reform and innovation, we must promote the innovation of rural financial products and services mode actively. Therefore, it is of great significance to research the innovation of rural financial products and services:

\section{The Demands of Building a New and Perfect Rural Financial System}

The innovation of rural financial products and services includes many aspects: the content of the involved products, business, institution, system, idea, process and so on. The innovations contribute to build efficient rural financial system, to serve "agriculture, rural areas and farmer" and complete the grand blueprint of well-off society.

\section{The Needs of Agricultural Industrial Structure Adjustment}

With the constant adjustment and development of China's economic and industrial structure, the diversified development pattern of rural economy has become increasingly prominent. many factors are affected by this change, such as planting, aquaculture, breeding, processing of agricultural products. It leads to farmers and agricultural enterprises have become diversified demand for funds. In order to fit in the new era of change, in accordance with the needs of the adjustment of agricultural industrial structure. It is necessary to consider the type, interest rate, term even many more aspects while carrying on financial products innovation such as credit products, financial products.

\section{The Needs of Developing the Rural Market and Gain Better Returns}

With the science and technology are becoming stronger, the development of the financial industry has becoming more perfect, various a wild range of financial institutions continue to emerge. The state attaches great importance to the development of the rural finance, all kinds of domestic banks, foreign banks, non bank financial institutions have set up various types of rural banks to enter the county to provide financial services. Therefore, the competition is more intense, rural finance reform is imperative. Innovation is the source of progress, which is conducive to the formation of a healthy competitive situation in rural financial markets [3], to gain the competitive advantage and profit.

\section{The Needs of Preventing and Defusing Financial Risks for Rural Areas}

In order to provide more favorable conditions for rural financial products and service innovation, building the formation of rich rural financial institutions is the main work .For the reform of the rural financial system, setting up the modern financial management concept to improve the quality of service. It is benefit to improve the ability of guard against financial risks in rural areas and provide pluralistic and effective service for the "agriculture, rural areas and farmer". 


\section{The Interpretation of the Relevant National Support Policies}

With the problem of "agriculture, countryside and farmers" becoming more and more apparent, the state emphasizes the necessity and urgency of solving the problems of "Three agriculture". Government policy makers attach great importance to the development of the rural economy and give a explicit elucidation on the development of rural finance.

\section{Policies to Support Financial System Reform and Innovation}

In 2005, the Central Document No. 1pointed that to promote the reform and innovation of rural financial system. To explore and create more-closest demand of farmers and rural, accelerate the establishment and implement a variety of mortgage guarantee mode, guarantee the construction of the rural capital requirements to meet. In 2008, the central documentNO.1 content proposed to speed up the rural financial system reform and innovation, and actively cultivate microfinance organizations, supported the development of positive credit and coinsurance loans to support the positive development of credit guarantee and guaranteed loans. In addition, to promote the innovation of rural security, and expand the effective use of collateral category. In 2014, the central file once again called for speeding up the rural financial system innovation, emphasizing the financial institutions to serve the "agriculture, countryside and farmers", developing the new type of rural cooperative financial organizations, and strengthen the support of agricultural insurance. In 2015, the central requirement actively promote reform of the rural financial system, according to the actual situation of rural development, the demand characteristics of agriculture development and the diversity needs of farmers continue to strengthen the rural financial reform and innovation.

\section{Policies that Support Financial Institutions to Establish and Develop Innovative}

In 2006, the central file NO.1encourages farmers to establish capital mutual aid organizations, establishing and improving of the security fund organizations and institutions. The China Banking Regulatory Commission issued the polices about the adjustment of financial institutions in rural banking to relax access, providing more financial institutions and trading platform. In 2007, the central document pointed out that financial institutions should increase the intensity of the "agriculture, countryside and farmers" credit involved, and provide material basis for the development of modern agriculture. Introduced the Provisional Regulations of village banks, loan companies, rural fund cooperatives, supported the form for examination and approval work index, and promoted the new type of rural financial institutions in rural banks, loan companies and rural mutual cooperatives, vigorously expand around. Subsequently, the China Banking Regulatory Commission, the People's Bank issued on small loan company pilot guidance, makes the establishment and rapid development of micro credit companies around the country. In 2013, the China Banking Regulatory Commission published indications on deepening the financial services of the small and micro enterprises, the requirement continued to the regulatory policy of differential supervision for small and micro finance.

\section{Policies to Support Innovation in Financial Products and Services}

The People's Bank and Chinese Banking Regulatory Commission decided to set innovation pilots in six central provinces and three northeastern provinces in 2008. The pilots will carry out the plan for rural financial products and services. Mentioned in the central file NO.1, 2009, it strengthened the ability of rural financial services and encouraged financial institutions to rural financial products and financial services innovation. In 2010, the central document clearly states that innovative financial products and services, fully consider the characteristics of agricultural and rural needs, to guide credit funds to agriculture, rural area, and farmers. The central bank and other four ministries comprehensively formulated the guiding opinions on promoting the innovation of rural financial products and services, mainly for household loans and guarantees problems. Developing the innovation activities in the rural finance service mode in national areas. In 2012, the central document proposed to improve the existing level of financial services in rural areas, increase the intensity of agricultural loans and improve the fiscal and taxation policies, etc. In 2013, the central 
stressed that improve rural financial services, increase the intensity of commercial financial support for rural, continue to increase the supply of rural credit and innovative financial products and services. Issued by China Banking Regulatory Commission on the support of "three major projects", the rural small and medium financial institutions to give full priority to promote the financial benefits of farmers and project finance innovation, and actively meet the diverse needs of services. Actively innovating products and services flow cost, easy to imitate the replication, universal promotion, popularization and diversification . Increasing the intensity of product service innovation. In 2016, the central document to make clear that the direction of financial resources to rural areas and promote the development of Internet banking, improve the service of efficiency and quality.

It is not difficult to see from the above policies, the support policy of the state on encouraging rural financial development is increasing, then a variety of new rural financial institutions emerge constantly. In terms of financial products and services innovation and promotion, our country also give a more reasonable standard system and support. Accelerating the pace of financial institutions for financial products and services innovation, at the same time, we also pay attention to enrich of products and services. The innovation of financial products and services can provide more capital supply platform for rural areas, which is also the leading ideological line of the country to the rural financial policy .Helping to promote the development of rural finance and improve the level of rural economy.

\section{The Connotation about the Innovation of Rural Financial Products and Services in China and} Abroad

\section{The Definition of Financial Products and Services in Domestic and Foreign Academic Circles}

\section{The Definition of Financial Products}

There are a lot of theories about financial products, probably we can probably sum up the following views:

For the essence of financial products, Goldsmith said: Financial products are intermediary tools for trading. It also is a kind of certificate proof of credits and debts; It can be regarded as collateral or not collateral loans, which hand out to the government, enterprises or individuals; life insurance or endowment insurance; Short-term commercial credit business; Represented by stock of stock right.

About contractual features, Da HUANG's view is that a financial instrument is a written document. It can confirm the details of the transaction. It has legal effect for creditor and debtor. Beyond enlightenment, the financial products have shown many characteristics such as profitable, different deadline, circulative and credit risk .

From the perspective of the function of financing, financial products can be divided into market and intermediary. Financial products in the market economy including stocks, bonds, futures contracts, financial derivatives. It can be directly used for transactions by the agent. Financial intermediary products such as bank deposits ,bank loans and insurance contracts, Trading in financial intermediaries by commercial man .

\section{The Definition of Financial Services}

In the western countries, the definition of financial services was comprehensively defined in 50s and $60 \mathrm{~s}$.

Adam Smith, the founder of economics, believes that services is the material products or labor behavior to meet the needs of various social roles. In 1960, the American Marketing Association defines the meaning of the financial services connotation: financial services is an activity for sales, which can bring benefits and satisfaction indirectly; In 1963, Regan defined financial services as the specific activities that are provided to meet the need of the customer demand or the abstract activities which are provided with the material; In 1990, Ms. Groner summarizes the meaning of financial summary service :dealing with many of the problems of relating to the consumer by the 
way of abstraction , not just simple operational services; In the 90s, Philip Kotler defined financial services as an abstract behavior for producing interest, without evident achievement and extend to ownership issues.

Comparing with foreign countries, the research of financial services is relatively late in China, many scholars have defined the financial services from many angles, so that produce many new viewpoints and theories.

Hong TAN believes that the financial services is financial transactions of providing tangible or intangible goods to customers by financial institutions, which meeting the demand. It is an activity, financial institution and the customer can be benefit. Ning CHE holds the views that financial services should include three aspects: the services of financial products, financial labor and financial assistant. Therefore, financial services satisfy the needs of human production activities and economic transactions, realizing the exchange of material needs. It is essentially a specific services to provide for customers, at the same time, obtaining benefits from it [4].

\section{The Theory of Rural Financial Products and Services Innovation}

\section{The Theory of Rural Financial Products Innovation}

The essence of rural financial innovation is to improve or reconfigure some basic elements such as financial products, organizational structure and financial system. Thus, the innovation of rural financial product belongs to the category of rural financial innovation. Specifically, the definition of rural financial product innovation: we must support the innovation of financial products and services in rural financial market, using the new ideas and new technologies through various types of formal and informal financial institutions. In order to provide financial tools and supporting services for rural customers. Then, it formed a series of economic activities, achieving their own development and common interests [5].

It is called the absorbing innovation that develop the financial product innovation base on the original financial products; developing new financial products as the original financial product innovation. Through the adjustment and reorganization of the original financial products, we can get more new financial products to satisfy the needs of modern times.

\section{The Theory of Rural Financial Service Innovation}

The definition of innovation comes from Schumpeter. Rural financial service innovation can be regarded as a new combination of the elements of rural financial services. Rural financial services innovation can be a process, which is considering financial tools and new technology as the foundation, meeting diversified demands of the rural customers by communicating with customer and transferring the financial services channels, so as to realize their own profit maximization. In this paper, the connotation of rural financial service innovation including formal and informal organization of financial services, involving innovation in many ways such as the financial business, financial management.

\section{The Connotation of the Innovation of Rural Financial Products and Services}

\section{Objectives of Rural Financial Products and Services Innovation}

The innovation of rural financial products and services should be taken into consideration for the purpose of serving "agriculture, rural areas and farmer". It related to the overall situation of the country's development and a country's long-term stability. It is a important symbol for improving the rural financial system, which serves for "agriculture, rural areas and farmer", innovates financial products and services mode that fit the request of "agriculture, rural areas and farmer", and improves the efficiency of rural financial services.

\section{The Principle of Rural Financial Products and Services Innovation}

\section{The Principle of Virtuous Circle}

Economy decides finance and finance reacts to economy [6]. when innovating the rural financial 
products and services, we should grasp the benign interaction between the development of rural economy and rural finance, thus we can allocate the rural economic resources reasonably. Therefore, the innovation of rural financial products and services regard improve the level of rural economy as the goal, and the high level of rural economy can promote the development of rural finance in turn. Finally it can achieve a virtuous cycle between the two sides.

\section{The Principle of Reasonable Cost}

The innovation of rural financial products and services should be based on the economic situation of the needs of the group and budget and plan the cost of innovative products and services reasonably. Especially in the rural areas security mechanism is not perfect currently when the borrowing needs increasing. It is asked to design the reasonable credit mechanism, which can extend to the size of the trade that both can provide more financial support to agriculture, and ensure the popularization and use of products and service.

\section{The Principle of Reality Local Conditions}

The characteristics and conditions of every rural economy are dissimilar, so financial institutions related agriculture should be based on the level of regional economic development, taking into account the differences of different subject demand, innovating financial products and services what are easy to accept and strong operation with the different situations of different countermeasures, developing products with regional characteristic.

\section{The Principle of Risk Management}

We should deal with the relationship between financial products and service innovation and conduct risk test in the development stage, risk management in the use stage, strict implementation of risk prevention measures, strengthen personnel training to prevent various risks effectively.

\section{The Principle of Market Orientation}

In the process of innovation, we should seize the diversified needs of rural finance, and give full play to the function of market mechanism. Therefore, the rural financial products and services involved in all aspects, such as management, system ,service, etc, must be market-oriented. In addition, we should combine the development of rural economic with the development of rural financial services to form a perfect rural financial system so that the operation can be more healthy and orderly.

\section{The Principle of Coordinated Development}

Promoting the innovation of rural financial products and services is not only involves in the field of finance internal reform, but also need consider the coordinated development between various industries into such as the simultaneous development between agriculture and city and the coordinated development between agriculture and industry.

\section{Evaluation Criteria of Rural Financial Products and Services Innovation}

To innovate of rural financial products and services, Firstly, it should achieve safe, practical, convenient, mature, efficient and customer satisfaction; Secondly, according to different characteristics of different regions, we should innovative products and services with local characteristics and combine with regional characteristics; Finally, in the service object and function, we can have a unique feature.

\section{The Basic Conditions of Innovative Products and Services}

It can be summarized as the following five aspects: Firstly, security. It mainly ensures that the safety of customers' funds through banks or ensures customers' safety experience in the service process. At the same time we should improve the risk management system to ensure the safety in the process of using funds; Secondly, practical value and convenience. Convenient and efficient product function design can win the customer's favorite, according to the needs of customers to design practical 
products and services; Thirdly, maturity. The development of the product has been tested many times, so it can be accepted and used by customers; Fourthly, effectiveness. Products and services can not only bring benefits to customers, but also bring benefits to financial institutions; Fifthly, customer satisfaction. For example, the convenience of using products, the degree of risk and benefits, service attitude, service efficiency.

\section{Innovative Products and Services Should Have Local Characteristics}

Whether reflecting local characteristics or not, there is the following characteristics to check: firstly, scope of services, including service area size, the number of customers and the coverage size, relevant sizes of the transaction amount; Secondly, whether it can reflect the regional economic and financial development characteristics through these products and services or not; Thirdly, whether it can promote local economic development and increase the economic vitality or not; Fourthly, in the superior state of development, whether it can play an exemplary role or not .

\section{The Service Object and Function of Innovation should be Characteristic}

On the one hand, service object or product sales targets mainly towards to farmers, small and medium-sized enterprises, serving the agriculture, which can reflect the social value of the level of products and services; On the other hand, original products and service function is unique, it is worthy of popularization and application. Because it is based on the characteristics of the local improvement, so the function is more practical and can be widely accepted. What is more ,service efficiency is relatively high.

\section{The Characteristics of Rural Financial Products and Services Innovation}

\section{Creativity}

Innovation is a Kind of Creative Process. In order to improve the core competitiveness of financial institutions, we must focus on the development of innovative financial products and services to meet new demands by a constantly changing market environment. During the process of innovation, producting the concept of innovation, research and development, operation and promotion, expressing creativity everywhere .

\section{Marketability}

The innovation of financial products and services, starting from the market requirement ,designing products and services should be combined with changes and demands in market, and product price positioning. According to the price of financial products as a reference standard, the success or failure of product innovation to market test as the final standard. It can be seen that the whole process of rural financial products and service innovation should consider the market.

\section{High Input.}

First of all, from the concept of innovation to research and development, then on trial and implementation, a successful innovation need to go a long process. it also will invest a lot of manpower and material resources; Secondly, as the society makes continuous progress and the technology is also changing, so that the demand scale of continues to increase, The complexity of R \& D continues to deepen, the investment is increasing; Finally, in the rural market, the demand subject and the demand level shows multiplex development tendency that requires high investment to satisfy it.

\section{High Risks}

On the one hand, the whole innovation process demands a huge investment, resulting in high cost; On the other hand ,the realistic environment exists all kinds of uncertainty elements such as natural risk, market risk, social risk and moral risk, those factor may lead to high risk . 


\section{Reference}

Original innovation means that the results are being invented from scratch. The referential innovation stands for improving the level of existing product and service model. Due to our rural development relative lag, rural financial products and services innovation started relatively late, mostly learning from foreign or developed cities experience of innovation.

\section{Relative Conservatism}

Based on the complex environment of China's rural market, it is difficult to grasp the characteristics of financial products and services innovation, so it hobbles the development of innovation activities. Blindly carry out all aspects of innovative products, it will increase the burden on investment, however, can't achieve the desired results. Therefore, we can take a relatively conservative approach, for example, "experimentation precedes popularization", It will not only reduce the cost of innovation, but also enhance the efficiency of financial services.

\section{Rural Nature}

This is the unique nature of rural financial products and services innovation. Mainly reflected in the following three aspects: Firstly, the purpose of products and services innovation is to meet the needs of farmers, rural finance and rural economic development; secondly, in the process of innovation, we should take into account the factors such as the forest right, land use right; thirdly, the service scope involves the rural market and the service object is peasants.

\section{Put Forward the Content of Rural Financial Products and Service Innovation}

\section{Innovation of Rural Financial Products}

\section{Enriching the Contents of Rural Financial Products}

The core of financial products innovation is the contents of financial products. Actively developing new loan types is the basic contents of innovating financial products, for instance, the start-up loan of farmer workers, agricultural loans; secondly, creating the way about loan, such as Forestry Right Mortgage Loan, inventory pledge loan, we can use the new types of loans so that increasing the type of loans and reducing credit risk.

\section{Stabilize Rural Financial Product Pricing Mechanism}

Various financial institutions according to the needs of the interest rate marketization, combining its own characteristics, gradually establishing pricing system of financial products which is considering the price in market as guidance, reducing interest rate risk, improving the comprehensive income as the goal .Through the reasonable market price, to regulate the amount of deposits and loans, to obtain the reasonable income. In addition, financial institutions should also implement differentiated interest rate to different categories of customers .Through the optimal allocation of funds to meet the diverse needs of different customers, thereby enhancing comprehensive service ability of financial institutions.

\section{Innovate Intermediary Business}

Based on the survey and research, Financial institutions grasp the situation of the demand in rural financial market, Targeted developing new financial products to serve the countryside, expanding the business as much as possible, at the same time, creating a development space to increase the intermediate business. For example, through the promotion of mobile technology for banking, the construction of villages and towns. The network transaction mode of rural financial products can be widely accepted and used, Constantly enriching the product chain [7].

\section{Innovating the Collaboration Pattern between Insurance Products and Financial Institutions}

According to the changes of market demand, financial institutions renew insurance products in time. 
Coupled with the cooperation with various financial institutions, it is conducive to the promotion of insurance products. For example, financial institutions can cooperate with insurance companies to carry out insurance business, on the one hand, the way can ensure the development of insurance business, on the other hand ,distribute credit risk. From 2007 to 2014, agricultural insurance to provide risk protection increased from $\$ 1$ trillion and 660 billion to $\$ 112$ billion 600 million, the annual growth rate averaged $57.09 \%$, providing total risk protection for 5 trillion and 720 billion yuan [8].

\section{The Innovation of Rural Financial Service}

\section{The Concept of Financial Services}

Establishing the concept of financial services which takes the customer as the core, network supported by information network technology, Based on Organizational Innovation and process optimization. It's forming excellent financial service culture, to improve the rural financial institutions of "soft power". Service concept determines the service behavior, and affects the quality of service. Hence, updating and innovating the concept of service in time that can promote service to meet the demand of customers[9].

\section{Innovative the Process of Financial Service}

Whether the service process is reasonable or not, the financial service efficiency will produce influence directly. Therefore, the financial institutions should be based on the needs of the customer's convenience and constantly improve the system of innovative services, providing standardized service facilities and standards.

\section{Innovative the Way of Financial Services}

Providing financial services to customers, financial institutions should strengthen the security education and collect feedback from customers. From the perspective of customers, innovating the way of financial services, optimizing and upgrade the system function. We also can learn the thinking way of Internet, allowing customers to experience the new financial products and services, so that customers can get a good sense of experience and improve customer satisfaction [10].

\section{Innovative the Management of Financial Services}

The traditional financial business management is mainly on account management. With the development of financial market and the increasingly competition, financial institutions can innovative financial services in the financial management, establish the unified data platform, integrate the association data[11] ,further refine the classification of information management, integrate the customer resources and improve the level of service.

\section{Acknowledgements}

Fund Program: This paper is a major application research project of philosophy and social sciences in Henan province (project number: 2017-YYZD-17), one of the research achievements of philosophy and social sciences planning project (project number: 2016BJJ048).

A brief introduction of the author: Ming-Gui CAO(1964.12-), male, born in Huangchuan, Henan province. At present, author holds the office of secretary of party committee and professor of Tourism Department of Xinyang Normal University, Henan province ,devoted to the research of regional economy.

\section{Reference}

[1] NanYE . Research on the innovation of rural financial products under the background of urban and rural development in Changan District [D]. Urumqi: Xinjiang Agricultural University, 2013:4-8.(In Chinese) 
[2]Jia-KeLI. The contradiction between financial supply and demand and its sustainable development in rural areas of China [J]. reform and strategy, 2017 (03).(In Chinese)

[3]Guang-Ming YU. Research on financial service innovation of Fujian rural credit cooperatives [D]. Fuzhou: Fujian Agriculture And Forestry University, 2013:2-5.(In Chinese)

[4] Zhi-GuoWANG. Research on the innovation and development of rural financial services in Jilin province [D]. Changchun: Jilin University, 2014:3-9.(In Chinese)

[5] LanWEI. Research on the innovation of rural financial products and services [D]. Changchun: Jilin University, 2013:80.(In Chinese)

[6] JiaoFu. Research on the innovation of rural financial products based on demand [D].. Xiangtan. Xiangtan University, 2014:10.(In Chinese)

[7] Xiu-RuLI. Research on the innovation of rural financial products and services from the perspective of function [J].Journal of Agricultural Science Yanbian University, 2013:344-326.(In Chinese)

[8] Yan PENG. Research on the innovation and development of rural financial products and services [D]. Yangling: Northwest Agriculture and Forestry University, 2015:13.(In Chinese)

[9] Xue-YanTU. Research on innovation strategy of Yunnan rural credit financial products and services[D]. Kunming:Yunnan University, 2015:27-29.(In Chinese)

[10] Yan PENG. Factors restricting the innovation of rural financial products and its solutions [J]. Xi'an University Of Architecture And Technology, 2015 (05).(In Chinese)

[11] Ying GUO. A new model of postal rural financial service based on thinking in the Internet [J]. post research, 2017 (01).(In Chinese) 